\title{
Molecular screening of the human melanocortin-4 receptor gene: identification of a missense variant showing no association with obesity, plasma glucose, or insulin
}

\section{T. G otoda, J . Scott, T.J . A itman}

Molecular Medicine Group, MRC Clinical Sciences Centre, Royal Postgraduate Medical School, Hammersmith Hospital, London, UK

Summary Disruption of the melanocortin-4 (MC-4) receptor gene in mice results in maturity-onset obesity, hyperinsulinaemia and hyperglycaemia. These phenotypes are characteristic of human obesity that frequently accompanies non-insulin-dependent diabetes. It is therefore possible that human MC-4 receptor gene mutations contribute to human obesity. To test this possibility, we examined by DNA sequencing the entire coding region of the human $\mathrm{MC}-4$ receptor gene in 40 morbidly obese $(\mathrm{BMI}>35 \mathrm{~kg} /$ $\mathrm{m}^{2}$ ) white British males and examined the $5^{\prime}$ - and $3^{\prime}$ flanking regions in 20 out of these obese subjects. We also sequenced all these regions in 10 lean $\left(\mathrm{BMI}<18 \mathrm{~kg} / \mathrm{m}^{2}\right)$ white British males for a reference. We identified a single nucleotide substitution that replaces valine with isoleucine at codon 103, in two obese subjects in the heterozygous state. No other nucleotide alterations were found. The prevalence of this missense variant was studied in 322 white British males $\left(190\right.$ with $\mathrm{BMI}>28 \mathrm{~kg} / \mathrm{m}^{2}$ and 132 with BMI $<22 \mathrm{~kg} / \mathrm{m}^{2}$ ) selected from a population-based epidemiological survey. In these subjects, no homozygotes for the isoleucine allele were found. The frequency of heterozygotes was similar ( 4.2 vs $4.5 \%$ ) in the two groups and there was no significant difference in BMI, total skinfold thickness, plasma insulin and glucose levels between heterozygotes and codon-103 valine homozygotes in either group. These results suggest that coding sequence mutations in the MC-4 receptor gene are unlikely to be a major cause of human obesity, at least in white British males. [Diabetologia (1997) 40: 976-979]

Keywords Obesity, hyperinsulinaemia, genetics, gene variant, melanocortin, receptor, agouti.
Obesity is the most common metabolic disorder in Westernised countries. The metabolic sequelae of insulin resistance, diabetes mellitus, hypertension and hyperlipidaemia are associated with major morbidity, mortality and health care expenditure. Family studies have identified a genetic component in human obesity,

Received: 10 March 1997 and in revised form 9 May 1997

Corresponding author: Dr. T.J. Aitman, Molecular Medicine Group, MRC Clinical Sciences Centre, Royal Postgraduate Medical School, Hammersmith Hospital, Du Cane Road, London W12 0 NN, UK

A bbreviations: MC-4, Melanocortin-4; bp, base-pair; PCR, polymerase chain reaction; 3'-RACE, rapid amplification of complementary DNA $3^{\prime}$-end; OGTT, oral glucose tolerance test; NPY, neuropeptide Y. although, as yet, these genetic determinants remain largely unknown [1].

In contrast, genetic analysis of mouse models of monogenic obesity has recently led to the identification of five "obesity genes": agouti, ob, fat, $\mathrm{db}$ and tub. Among these gene loci, dominant alleles at the agouti locus cause a change in coat colour and a pleiotropic obesity syndrome in the mouse, as a consequence of ectopic expression of agouti peptide, a high-affinity antagonist of the melanocyte-stimulating hormone receptor in the skin and of the melanocortin-4 (MC-4) receptor in the hypothalamus [2]. Recently, it has been shown that intracerebroventricular administration of agonists or antagonists of hypothalamic melanocortin receptors inhibited or stimulated, respectively, the feeding behaviour in several mouse models of hyperphagia [3]. Moreover, 
targeted disruption of the MC-4 receptor gene in mice results in maturity-onset obesity, hyperinsulinaemia and hyperglycaemia, resembling the agouti obesity syndrome [4]. These observations indicate that the agouti obesity syndrome is caused by chronic antagonism of the MC-4 receptor.

Human obesity is also a maturity-onset disorder associated commonly with metabolic abnormalities such as hyperinsulinaemia and hyperglycaemia. Obese humans commonly have increased plasma levels of leptin [5], the circulating product of the ob gene, and MC-4 receptor knockout mice also have very high blood levels of leptin [4]. It is therefore possible that genetic defects in $\mathrm{MC}-4$ receptor contribute to obesity in humans. In this study, we determined the DNA sequence of the human MC-4 receptor gene of either extremely obese or lean subjects and examined the significance of an identified missense variant on the development of human obesity and obesity-associated phenotypes.

\section{Subjects and methods}

Subjects. White British men aged 40-64 years with both parents born in Britain were selected from the 1988-1990 population-based epidemiological survey of factory workers and Family Practitioner lists in Southall, west London [6]. Of 1262 consecutively sampled white males from the original survey, blood samples were available for DNA extraction from $97 \%$ of the males. In this population the frequency of diabetes was $4.5 \%$ and of impaired glucose tolerance or diabetes $7.2 \%$. Because comparison of extremes in populations provides the most power to detect genetic effects on quantitative traits, white males of British descent with BMI above $28 \mathrm{~kg} / \mathrm{m}^{2}$, defined here as obese (range $=28.0-51.2 \mathrm{~kg} / \mathrm{m}^{2} ; \mathrm{n}=190$ ), or less than $22 \mathrm{~kg} / \mathrm{m}^{2}$, defined here as lean (range $=16.1-22.0 \mathrm{~kg} / \mathrm{m}^{2}$; $\mathrm{n}=132$ ), were selected for analysis $[6,7]$. In the obese sample 19 subjects $(10.1 \%)$ were diabetic and 10 additional subjects $(5.3 \%)$ had impaired glucose tolerance. In the lean data set one subject $(0.8 \%)$ was diabetic and one additional subject $(0.8 \%)$ had impaired glucose tolerance. DNA was also extracted from blood samples of $50 \mathrm{UK}$ resident Asians. The study was approved by the relevant local research ethics committees. Informed written consent was obtained from all study subjects.

A nalysis of M C-4 receptor gene. Human MC-4 receptor is a protein of 332 amino acids encoded by a single exon [8, 9]. Four separate DNA fragments that cover the previously reported 1671 base-pair (bp) genomic sequence [9] encompassing the entire MC-4 receptor coding region were amplified from leukocyte DNA by the polymerase chain reaction (PCR). PCR amplification was performed as described previously [7] with annealing temperature $\left(55^{\circ} \mathrm{C}\right), \mathrm{MgCl}_{2}$ concentration $(1.0 \mathrm{mmol} / \mathrm{l})$ and the following PCR primers: Forward (reverse) primer, Fragment 1, 5'-AGCTTCCGAGAGGCAGCCGA-3' (GTTCCAGAGGTGCAGAGAAG); 2, ATCAATTCAGGGGGACACTG (GACAGCACTACTATCTGAGT); 3, ATGCTCTCCAGTACCATAACA (TGCAGAAGTACAATATTCAGG); 4, CACTCCGGAGTCAAGAACTG (AAGCTTTTAATAAGGACTTTTCT). Fragments 2 and 3 were for analysis of the coding region and Fragments 1 and 4 were for analysis of the $5^{\prime}$ - and 3 -flanking regions, respectively. PCR products were sequenced as described previously [7] by cycle-sequencing method.

A nalysis of $3^{\prime}$ end of hypothalamic M C-4 receptor mR NA. The $3^{\prime}$ end of hypothalamic MC-4 receptor mRNA was analysed by rapid amplification of complementary DNA 3'-end (3'RACE). Briefly, human hypothalamus RNA (1 $\mu \mathrm{g})$ was pretreated with RNase-free DNase (Promega, Madison, WI, USA) and was reverse-transcribed in $25 \mu \mathrm{l}$ of reaction mixture as described previously [7] with $0.5 \mu \mathrm{g}$ of oligo-dT primer attached with an adapter sequence (GACTCGAGTCGACATCGATTTTTTTTTTTTTTTTT). One-tenth of the product was amplified by PCR with the forward primer for the Fragment 4 and a 17-mer adapter primer (GACTCGAGTCGACATCG).

G enotyping. Genotyping of the DNA sequence variant at codon 103 was carried out by PCR-RFLP analysis. Genomic DNA ( $50 \mathrm{ng}$ in $25 \mu \mathrm{l}$ reactions) was amplified by PCR (annealing temperature, $50^{\circ} \mathrm{C} ; \mathrm{MgCl}_{2}$ concentration, $\left.1.2 \mathrm{mmol} / \mathrm{l}\right)$ with primer A (ATGGAGGGTGCTACGAGCAACT) and primer B (TCTGTACTGTTTAATAGgGTGTTG). Primer B has a sequence mismatch in its $3^{\prime}$-region (underlined) in order to create an artificial restriction site for $\mathrm{H}$ inc II in the PCR products derived from the valine allele. PCR products $(7 \mu \mathrm{l})$ were digested overnight in a $15 \mu \mathrm{l}$ reaction mixture with $10 \mathrm{U}$ of $\mathrm{H}$ inc II and were analysed on $4 \%(3: 1 \mathrm{NuSieve}$ : normal, FMC Bioproducts, Rockland, ME, USA) agarose gels.

Statistical analysis. Frequencies of genotypes between obese group $(n=190)$ and lean group $(n=132)$ were assessed by chi-square analysis. Differences between groups with different genotypes were assessed by Student's t-test or by multivariate regression analysis including age as a covariate. Total skinfold thickness was defined as the sum of subscapular, suprailiac, anterior thigh, suprapatellar skinfold thickness. Analyses of insulin, glucose and triglycerides used log-transformed values. All statistical analyses were performed using the STATA program (Stata Corp, College Station, TX, USA).

\section{Results}

We examined by DNA sequencing the entire coding sequence of the human MC-4 receptor gene, which encodes a $\mathrm{G}$ protein-coupled, seven-transmembrane receptor of 332 amino acids [8,9], in 40 extremely obese $\left(\mathrm{BMl}=35.1-51.2 \mathrm{~kg} / \mathrm{m}^{2}\right)$ and 10 extremely lean $\left(\mathrm{BMl}=16.1-17.8 \mathrm{~kg} / \mathrm{m}^{2}\right)$ white British males. In 20 of these obese and 10 of these lean subjects, the DNA sequence of the 5'- and 3'-flanking regions (373 bp and $256 \mathrm{bp}$ in length, respectively, except for primer sequences) [9] were also examined. We found a single base substitution that replaces the published sequence for isoleucine (ATC) [8,9] with that for valine (GTC) at codon 103 (Fig. 1 A). Interestingly, the published sequence (ATC) at codon 103 was rare in British subjects, since, in the 50 subjects studied by sequence analysis, 48 were homozygous for the valine (GTC) allele and only two obese subjects were heterozygotes, with no isoleucine-allele (ATC) homozygotes. Codon 169, at which Gantz et al. [8] reported an isoleucine (ATC) sequence and Mountjoy et al. [9] did a serine (AGC) sequence was isoleucine (ATC) 
A

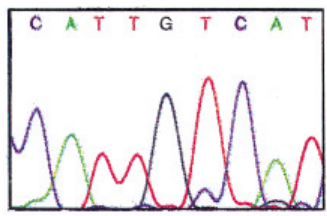

Homozygote (Val / Val)

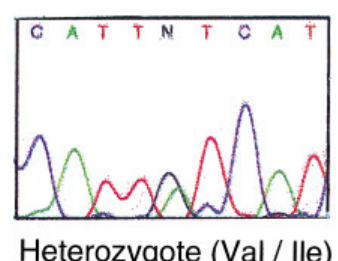

B
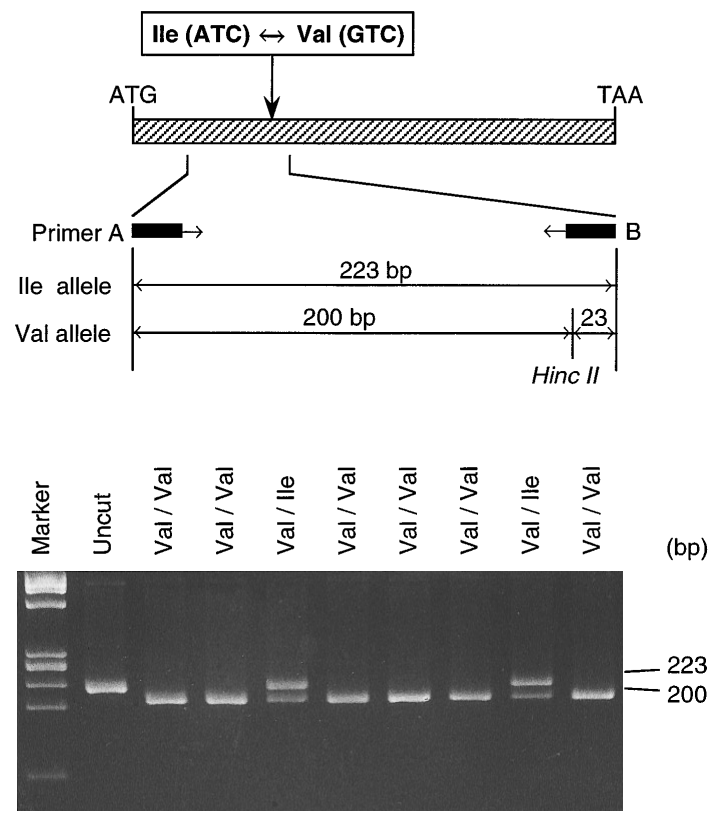

Fig. 1. A Sequence electropherograms representing the missense gene variant (GTC $\leftrightarrow$ ATC) at codon 103 of the human MC-4 receptor gene. Sense-strand sequences are shown for a homozygote for the valine (GTC) allele (left) and for a heterozygote (right). B Genotyping of the Val103lle missense gene variation. (Upper) Schematic representation of the position of the Val103lle variation in the human MC-4 receptor coding region (hatched), with magnification of the region amplified by PCR for genotyping. The $223 \mathrm{bp}$ DNA fragment was amplified with primers $\mathrm{A}$ and $\mathrm{B}$, which introduced an artificial $\mathrm{H}$ inc II restriction site into the PCR products derived from the valine allele, and was digested with $\mathrm{H}$ inc II. (Lower) Genotyping by electrophoretic analysis of digested products on a $4 \%$ agarose gel. Marker: $\varnothing \times 174 / \mathrm{H}$ ae III; Uncut: undigested product

in all the 50 British subjects examined. We also found one additional adenine nucleotide in the 3'-flanking region, between nucleotides 1114 (A) and 1115 (T) of the published sequence [9], in all the 30 British subjects examined. No other sequence difference was found in comparison with previously published data $[8,9]$. Results of the $3^{\prime}$-RACE analysis showed that 3'-polyadenylation of human hypothalamic MC-4 receptor mRNA occurred 291 bases downstream of the termination codon (TAA).

The missense gene variation identified at codon 103 (Val103lle) could be detected by analysis of PCR-RFLP (Fig. 1B). To examine the possible significance of the Val103lle variation in the general population, we determined the genotype frequency for the Val103lle variation by PCR-RFLP analysis in 322 white British males (190 obese and 132 lean subjects) selected from an epidemiological survey population [6]. No homozygotes for the rare isoleucine allele were found in these 322 subjects. The frequency of heterozygotes was similar in both the obese and lean groups (4.2 vs $4.5 \%$ ). In these two groups, there were no significant differences, after Bonferroni correction for multiple tests, in BMI, total skinfold thickness, plasma levels of insulin, glucose and triglycerides (fasting and 2-h OGTT) between heterozygotes and others (Table 1). Considering that the sequence of codon 103 encoded an isoleucine residue in both of the two previous independent reports $[8,9]$, it seems likely that the isoleucine allele is much more common in certain populations. We therefore examined the frequency of the Val103lle variation in 50 UK resident Asians for comparison. The frequency was similar to that in British whites: two (4\%) were heterozygotes and the others were homozygotes for the valine allele.

\section{Discussion}

Recent results with MC-4 receptor knockout mice and neuropeptide Y (NPY) knockout mice, combined with the results with agonists and antagonists of hypothalamic melanocortin receptors, have suggested a novel framework for the system that regulates body weight [10]. The framework assumes the physiological responses to starvation (weight loss) as being distinct from the responses to obesity (weight gain): the former responses are triggered by decrease in leptin levels and mediated by hypothalamic NPY, whereas the latter responses are triggered by increase in leptin levels and mediated via hypothalamic MC-4 receptor pathways [10]. Human obesity is characterised by increased blood leptin levels or apparent "leptin resistance" [5], compatible with the disruption of the responses to weight gain, especially downstream of leptin production. This is exemplified by defects in the leptin receptor in $\mathrm{db}$ mice. However, to date, no such functionally defective mutations have been identified in the human leptin receptor gene [5, 7]. Abnormalities in the MC-4 receptor pathway may therefore contribute to development of human obesity. In the present study, we have identified a missense gene variation of the human MC-4 receptor through examination of the entire coding region of the human MC-4 receptor gene in 40 extremely obese or 10 extremely lean white British males. The only gene variation identified at codon 103 was not associated with human obesity or obesity-related phenotypes, although homozygotes for the isoleucine allele were not available for analysis because no homozygotes were found in either of the two populations examined. In 20 extremely obese and 10 extremely lean 
Table 1. Phenotypes of obese and lean white British males according to the genotypes of the Val103lle gene variant

\begin{tabular}{|c|c|c|c|c|c|c|}
\hline & \multicolumn{3}{|l|}{ Obese group } & \multicolumn{3}{|l|}{ Lean group } \\
\hline & $\mathrm{Val} / \mathrm{Val}$ & Val/lle & $P$-value & $\mathrm{Val} / \mathrm{Val}$ & Val/lle & $P$-value \\
\hline $\mathrm{n}$ & 182 & 8 & & 126 & 6 & \\
\hline $\mathrm{BMI}\left(\mathrm{kg} / \mathrm{m}^{2}\right)$ & $32.3 \pm 0.3$ & $31.5 \pm 1.6$ & 0.5 & $20.5 \pm 0.1$ & $20.1 \pm 0.7$ & 0.4 \\
\hline Total skinfold thickness (mm) & $102.3 \pm 1.9$ & $99.9 \pm 7.1$ & 0.8 & $41.6 \pm 1.2$ & $52.0 \pm 4.6$ & 0.05 \\
\hline Fasting plasma glucose (mmol/l) & $5.7 \pm 1.0$ & $6.2 \pm 1.1$ & 0.4 & $5.2 \pm 1.0$ & $5.0 \pm 1.0$ & 0.6 \\
\hline 2-h plasma glucose $(\mathrm{mmol} / \mathrm{l})$ & $5.6 \pm 1.0$ & $6.0 \pm 1.2$ & 0.6 & $4.4 \pm 1.0$ & $4.7 \pm 1.2$ & 0.6 \\
\hline Fasting plasma triglycerides $(\mathrm{mmol} / \mathrm{l})$ & $2.13 \pm 1.04$ & $2.06 \pm 1.19$ & 0.9 & $1.03 \pm 1.04$ & $1.10 \pm 1.31$ & 0.7 \\
\hline
\end{tabular}

Values are means \pm SEM. $P$-values were determined by Student's t-test

white British males, the $5^{\prime}$ - and 3 '-flanking sequences available with known information [9] were also examined. The sequenced 3'-flanking region (256 bp) was shown to correspond to most of the $3^{\prime}$-untranslated region (291 bases) of MC-4 receptor mRNA, but no mutations were found. Taken together, these results suggest that coding sequence mutations in the MC-4 receptor gene are not a major cause of human obesity, at least in white British males. However, this does not exclude coding sequence mutations in women, in other populations or in rare pedigrees, or mutations in further flanking regions as a cause of obesity. Exclusion of these possibilities must await further analysis of the unknown flanking sequence of the human MC-4 receptor gene (especially the 5'-promoter region) and linkage studies with flanking markers close to the human MC-4 receptor gene locus on chromosome 18 q21.3 [8].

A cknowledgements. We are indebted to Dr. P. M. McKeigue for blood samples and clinical data from the British subjects. T. G. was supported in part by a Sasakawa Health Science Foundation Fellowship.

\section{References}

1. Bouchard C (1996) The causes of obesity: advances in molecular biology but stagnation on the genetic front. Diabetologia 39: 1532-1533
2. Lu D, Willard D, Patel IR et al. (1994) Agouti protein is an antagonist of the melanocyte-stimulating hormone receptor. Nature 371: 799-802

3. Fan W, Boston BA, Kesterson RA, Hruby VJ, Cone RD (1997) Role of melanocortinergic neurons in feeding and the agouti obesity syndrome. Nature 385: 165-168

4. Huszar D, Lynch CA, Fairchild-Huntress V et al. (1997) Targeted disruption of the melanocortin-4 receptor results in obesity in mice. Cell 88: 131-141

5. Caro JF, Sinha MK, Kolaczynski JW, Zhang PL, Considine RV (1996) Leptin: the tale of an obesity gene. Diabetes 45: $1455-1462$

6. McKeigue PM, Shah B, Marmot MG (1991) Relation of central obesity and insulin resistance with high diabetes prevalence and cardiovascular risk in South Asians. Lancet 337: 382-386

7. Gotoda T, Manning BS, Goldstone AP et al. (1997) Leptin receptor gene variation and obesity: lack of association in a white British male population. Hum Mol Genet 6: 869876

8. Gantz I, Miwa H, Konda Y et al. (1993) Molecular cloning, expression, and gene localization of a fourth melanocortin receptor. J Biol Chem 268: 15174-15179

9. Mountjoy KG, Mortrud MT, Low MJ, Simerly RB, Cone RD (1994) Localization of the melanocortin-4 receptor (MC4-R) in neuroendocrine and autonomic control circuits in the brain. Mol Endocrinol 8: 1298-1308

10. Friedman JM (1997) The alphabet of weight control. Nature 385: $119-120$ 